\title{
Impact of body mass index on early and mid-term outcomes after surgery for acute Stanford type A aortic dissection
}

\author{
Yanxiang Liư ${ }^{\dagger}$ Bowen Zhang ${ }^{\dagger}$, Shenghua Liang, Yaojun Dun, Luchen Wang, Haoyu Gao, Jie Ren,
} Hongwei Guo and Xiaogang Sun *i)

\begin{abstract}
Background: Obesity is dramatically increasing worldwide, and more obese patients may develop aortic dissection and present for surgical repair. The study aims to analyse the impact of body mass index (BMI) on surgical outcomes in patients with acute Stanford type A aortic dissection (ATAAD).

Methods: From January 2017 to June 2019, the clinical data of 268 ATAAD patients in a single centre were retrospectively reviewed. They were divided into three groups based on the BMl: normal weight (BMI 18.5 to $<25$ $\mathrm{kg} / \mathrm{m}^{2}, n=110$ ), overweight (BMI 25 to $<30 \mathrm{~kg} / \mathrm{m}^{2}, n=114$ ) and obese (BMI $\left.\geq 30 \mathrm{~kg} / \mathrm{m}^{2}, n=44\right)$.

Results: There was no statistical difference among the three groups in terms of the composite adverse events including 30-day mortality, stroke, paraplegia, renal failure, hepatic failure, reintubation or tracheotomy and low cardiac output syndrome ( $20.9 \%$ vs $21.9 \%$ vs $18.2 \%$ for normal, overweight and obese, respectively; $P=0.882$ ). No significant difference was found in the mid-term survival among the three groups. The proportion of prolonged ventilation was highest in the obese group followed by the overweight and normal groups $(59.1 \%$ vs $45.6 \%$ vs $34.5 \%$, respectively; $P=0.017$ ). Multivariable logistic regression analysis suggested that $B M I$ was not associated with the composite adverse events, while BMI $\geq 30 \mathrm{~kg} / \mathrm{m}^{2}$ was an independent risk factor for prolonged ventilation (OR $2.261 ; 95 \% \mathrm{Cl} 1.056-4.838 ; P=0.036)$.

Conclusions: BMI had no effect on the early major adverse outcomes and mid-term survival after surgery for ATAA D. Satisfactory surgical outcomes can be obtained in patients with ATAAD at all weights.
\end{abstract}

Keywords: Body mass index, Acute Stanford type a aortic dissection, Frozen elephant trunk

\section{Introduction}

Obesity is causing an increase in cardiovascular morbidity, mortality, and health care cost $[1,2]$. An increase in the number of obese patients appearing with acute Stanford type A aortic dissection (ATAAD) has been observed over the years. Consequently, more obese

\footnotetext{
* Correspondence: xiaogangsun|@163.com

${ }^{\dagger}$ Yanxiang Liu and Bowen Zhang contributed equally to this work. Department of Vascular Surgery, State Key Laboratory of Cardiovascular Disease, Fuwai Hospital, National Centre for Cardiovascular Diseases, Chinese Academy of Medical Sciences and Peking Union Medical College, No.167 North Lishi Road, Xicheng District, Beijing 100037, China
}

patients are likely to present for surgical repair. A few studies have explored the outcome after surgery for ATAAD in obese patients [3-5]. However, the surgical procedures in these studies were diverse and included hemi-arch replacement, total arch replacement with or without frozen elephant trunk, or even isolated ascending replacement. And the inconsistency of surgical procedures may be a confounding factor affecting the results of these studies.

At present, total arch replacement with frozen elephant trunk (TAR with FET, sometimes called Sun's

(c) The Author(s). 2021 Open Access This article is licensed under a Creative Commons Attribution 4.0 International License, which permits use, sharing, adaptation, distribution and reproduction in any medium or format, as long as you give appropriate credit to the original author(s) and the source, provide a link to the Creative Commons licence, and indicate if changes were made. The images or other third party material in this article are included in the article's Creative Commons licence, unless indicated otherwise in a credit line to the material. If material is not included in the article's Creative Commons licence and your intended use is not permitted by statutory regulation or exceeds the permitted use, you will need to obtain permission directly from the copyright holder. To view a copy of this licence, visit http://creativecommons.org/licenses/by/4.0/ The Creative Commons Public Domain Dedication waiver (http://creativecommons.org/publicdomain/zero/1.0/) applies to the data made available in this article, unless otherwise stated in a credit line to the data. 
procedure) has become a routine surgical procedure to treat ATAAD in China since Sun and his colleagues introduced this surgery in 2006 [6].

The influence of obesity on surgical outcomes in ATAAD, particularly after TAR with FET, remains unclear. This study was designed to analyse the impact of varying body mass index (BMI) on early and mid-term clinical outcomes in ATAAD patients who underwent TAR with FET.

\section{Patients and methods \\ Patients}

From January 2017 to June 2019, 268 consecutive patients with ATAAD (within 14 days from the onset of symptoms to the operation) underwent TAR with FET at a single centre. All patients did not experience aortic rupture and cardiogenic shock before surgery. In our institute, TAR with FET is considered the first choice for patients with ATAAD younger than 60 years old,regardless of the location of the primary intimal tear (Hybrid surgery was performed in the patients older than 60 years old and with severe comorbidities). TAR can remove as much of the dissected aorta as possible while the FET was used to expand the true lumen, promote thrombosis of the residual false lumen and simplify the second-phase operation for the descending aorta. Patients were divided into three groups according to BMI and defined as: normal weight (BMI 18.5 to $<25 \mathrm{~kg} / \mathrm{m}^{2}$ ), overweight (BMI 25 to $<30 \mathrm{~kg} / \mathrm{m}^{2}$ ) and obese (BMI $\geq 30$ $\mathrm{kg} / \mathrm{m}^{2}$ ). Patients with BMI $\geq 35 \mathrm{~kg} / \mathrm{m}^{2}$ were included in the obese group due to the few cases $(n=6)$. None of the patients were classified as underweight group (BMI $<18.5 \mathrm{~kg} / \mathrm{m}^{2}$ ). This retrospective study was approved by the ethics committees of Fuwai Hospital, and written informed consent was waived.

\section{Surgical approach}

For all patients, the previously described TAR with FET, sometimes called Sun's procedure, was applied [7]. Sun's procedure was performed through a standard median sternotomy under cardiopulmonary bypass $(\mathrm{CPB})$ and selective cerebral perfusion (SCP) through the right axillary artery. Arterial cannulation was through the right axillary artery with the perfusion catheter directly inserted into the artery. During the cooling phase, aortic root procedures were performed if indicated. When the nasopharyngeal temperature reached $25^{\circ} \mathrm{C}$, circulatory arrest was instituted. After the three arch vessels were cross-clamped, antegrade SCP was started. To avoid recurrent laryngeal nerve injury, the aortic arch was transected between the left common carotid and left subclavian arteries. Subsequently, a stented graft was inserted into the true lumen of the descending aorta under direct vision. Then, the stented graft was anastomosed to a 4-branched graft in an end-to-end fashion using the open anastomosis technique. Distal reperfusion was initiated through the perfusion limb of the 4-branched graft once the distal anastomosis was completed. The left carotid artery was reconstructed first, followed by the ascending aorta to resume myocardial perfusion. Then the left subclavian artery was repaired, and, last, the innominate artery was repaired. After completion of the repair and adequate rewarming, the patient was weaned from $\mathrm{CPB}$, and the perfusion limb of the tetrafurcated graft was ligated and divided.

\section{Study endpoints}

The primary endpoint was composite adverse events and mid-term survival rates. Postoperative composite adverse events included 30-day mortality, stroke, paraplegia, renal failure, hepatic failure, reintubation or tracheotomy and low cardiac output syndrome. Stroke was defined as new brain injury that was clinically or radiographically evident after the procedure. Paraplegia was defined as lower limb strength less than or equal to grade 3 (able to resist gravity but not resistance). Renal failure referred to the need for haemodialysis during hospitalization. Hepatic failure was defined as a postoperative aminotransferase level exceeding $1000 \mathrm{IU} / \mathrm{L}$. Low cardiac output syndrome referred to the need for an intra-aortic balloon pump.

The secondary endpoint was prolonged ventilation which was defined as a postoperative intubation time more than $24 \mathrm{~h}$.

\section{Statistical analysis}

Data were reported as the mean \pm standard deviation or median with an interquartile range (IQR) for quantitative variables and as frequencies and percentages for categorical variables. For quantitative data, one-way ANOVA was used for normally distributed values and Kruskal-Wallis $\mathrm{H}$ test was applied for abnormally distributed values with or without homogeneity of variance. For categorical data, the Pearson $x^{2}$ test or Fisher's exact test was used to evaluate the differences in percentage. Survival was analysed by using the Kaplan-Meier method and log-rank tests.

Multivariable logistic regression analysis was applied to identify the risk factors for composite adverse events and prolonged ventilation. All potential covariates of interest were included in a univariable logistic regression model. The multivariable logistic regression model included significant variables $(P<0.1)$ in the univariable logistic regression. All the statistical tests were 2 -sided, and a $P$ value of $<0.05$ was considered to indicate statistical significance. All statistical analyses were done using SPSS version 25 (IBM, Armonk, NY). 
Table 1 Baseline patient characteristics

\begin{tabular}{|c|c|c|c|c|}
\hline Variables & Normal $(n=110)$ & Overweight $(n=114)$ & $\begin{array}{l}\text { Obese } \\
(n=44)\end{array}$ & $P$ value \\
\hline Age (years) & $47.1 \pm 9.4$ & $45.2 \pm 9.5$ & $45.2 \pm 7.4$ & 0.257 \\
\hline Male & $82(74.5)$ & $92(80.7)$ & $40(90.9)$ & 0.070 \\
\hline Hypertension & $89(80.9)$ & $94(82.5)$ & $39(88.6)$ & 0.519 \\
\hline CAD & $16(14.5)$ & $21(18.4)$ & $12(27.3)$ & 0.182 \\
\hline Diabetes & $2(1.8)$ & $4(3.5)$ & $2(4.5)$ & 0.578 \\
\hline Cerebrovascular events & $7(6.4)$ & $6(5.3)$ & $1(2.3)$ & 0.588 \\
\hline CKD & $2(1.8)$ & $0(0)$ & $1(2.3)$ & 0.298 \\
\hline $\mathrm{NYHA} \geq 3$ & $4(3.6)$ & $5(4.4)$ & $1(2.3)$ & 1.000 \\
\hline \multicolumn{5}{|l|}{ Organ malperfusion } \\
\hline Cardiac & $5(4.5)$ & $7(6.1)$ & $3(6.8)$ & 0.824 \\
\hline Cerebral & $5(4.5)$ & $6(5.3)$ & $1(2.3)$ & 0.859 \\
\hline Visceral & $2(1.8)$ & $1(0.9)$ & $1(2.3)$ & 0.668 \\
\hline Limb & $3(2.7)$ & $4(3.5)$ & $2(4.5)$ & 0.820 \\
\hline LVEF & $60(4)$ & $60(3)$ & $60(3)$ & 0.856 \\
\hline Moderate-to-severe AR & $30(27.3)$ & $30(26.3)$ & $10(22.7)$ & 0.851 \\
\hline
\end{tabular}

CAD coronary artery disease, CKD chronic kidney disease, NYHA New York Heart Association, LVEF left ventricular ejection fraction, AR aortic regurgitation Hypertension is defined as a systolic blood pressure greater than $140 \mathrm{mmHg}$

\section{Results}

\section{Patient characteristics}

Patient characteristics are summarized in Table 1. Of the 268 patients, $110(41.0 \%)$ patients were classified as normal weight, $114(42.5 \%)$ patients as overweight, 44 (16.4\%) patients as obese. Compared to normal weight patients, overweight and obese patients had a larger proportion of male gender, though the difference was not significant $(P=0.070)$. There was no significant difference among the three groups in terms of age, hypertension, coronary artery disease, diabetes, cerebrovascular events, chronic kidney disease, New York Heart Association class $\geq 3$, malperfusion syndrome, left ventricular ejection fraction and median or massive aortic regurgitation $(P>0.05)$.

\section{Operative data}

Operative details are listed in Table 2. TAR with FET was performed in all the patients. No significant difference was found in the concomitant surgeries. Also, cardiopulmonary bypass time, cross-clamp time and circulatory arrest time were close among the three

Table 2 Operative details

\begin{tabular}{|c|c|c|c|c|}
\hline Variables & Normal $(n=110)$ & Overweight $(n=114)$ & $\begin{array}{l}\text { Obese } \\
(n=44)\end{array}$ & $P$ value \\
\hline \multicolumn{5}{|l|}{ Combined surgery } \\
\hline Bentall & $32(29.1)$ & $30(26.3)$ & $9(20.5)$ & 0.547 \\
\hline Sinus reconstruction & $33(30.0)$ & $45(39.5)$ & $21(47.7)$ & 0.091 \\
\hline CABG & $18(16.4)$ & $21(18.4)$ & $12(27.3)$ & 0.290 \\
\hline Wheat's & $5(4.5)$ & $1(0.9)$ & $0(0)$ & 0.145 \\
\hline Other (David, Mitral, Congenital) & $7(6.4)$ & $2(1.8)$ & $2(4.5)$ & 0.186 \\
\hline CPB time (min) & $166.0(59.0)$ & $174.0(78.0)$ & $172.0(71.0)$ & 0.511 \\
\hline Cross-clamp time (min) & $109.0(48.0)$ & $112.0(50.0)$ & $101.5(52.0)$ & 0.656 \\
\hline Circulatory arrest time (min) & $16.0(3.0)$ & $16.0(4.0)$ & $16.5(3.0)$ & 0.517 \\
\hline \multicolumn{5}{|l|}{ Transfusion } \\
\hline Red blood cells (U) & $0(0)$ & $0(0)$ & $0(0)$ & 0.350 \\
\hline Fresh frozen plasma (ml) & $400(600)$ & $400(600)$ & $400(600)$ & 0.999 \\
\hline Platelets (U) & $1(1)$ & $1(0)$ & $1(0)$ & 0.105 \\
\hline
\end{tabular}

Bentall procedure was performed in the patients with severely dilated roots, or with the roots severely involved by the dissection 
Table 3 Early postoperative outcomes

\begin{tabular}{|c|c|c|c|c|}
\hline Variables & $\begin{array}{l}\text { Normal } \\
(n=110)\end{array}$ & Overweight $(n=114)$ & $\begin{array}{l}\text { Obese } \\
(n=44)\end{array}$ & $P$ value \\
\hline Composite adverse events & $23(20.9)$ & $25(21.9)$ & $8(18.2)$ & 0.882 \\
\hline 30-day mortality & $9(8.2)$ & $4(3.5)$ & $2(4.5)$ & 0.305 \\
\hline Stroke & $3(2.7)$ & $4(3.5)$ & $2(4.5)$ & 0.820 \\
\hline Paraplegia & $2(1.8)$ & $8(7.0)$ & $1(2.3)$ & 0.132 \\
\hline Renal failure & $12(10.9)$ & $13(11.4)$ & $5(11.4)$ & 1.000 \\
\hline Hepatic failure & $8(7.3)$ & $8(7.0)$ & $3(6.8)$ & 1.000 \\
\hline Reintubation or tracheotomy & $2(1.8)$ & $4(3.5)$ & $1(2.3)$ & 0.875 \\
\hline Low cardiac output syndrome & $3(2.7)$ & $1(0.9)$ & $1(2.3)$ & 0.487 \\
\hline ICU time (h) & $89.6(66.8)$ & $90.1(76.3)$ & $90.4(91.8)$ & 0.484 \\
\hline In-hospital time (d) & $10.0(5.0)$ & $12.0(6.0)$ & $11.0(7.0)$ & 0.173 \\
\hline Ventilation time $(h)$ & $20.9(22.9)$ & $22.0(44.8)$ & $30.4(60.7)$ & 0.039 \\
\hline Ventilation time $>24 \mathrm{~h}$ & $38(34.5)$ & $52(45.6)$ & $26(59.1)$ & 0.017 \\
\hline
\end{tabular}

groups. No significant difference was found among the three groups in the transfusion amount including red blood cells, fresh frozen plasma and platelets.

\section{Outcome characteristics}

Table 3 summarizes the early postoperative outcomes. The rates of composite adverse events were comparable among groups $(20.9 \%$ vs $21.9 \%$ vs $18.2 \%$ for normal, overweight and obese, respectively; $P=0.882$ ). And there were no significant differences among the three groups in terms of 30-day mortality, stroke, paraplegia, renal failure, hepatic failure, reintubation or tracheotomy or low cardiac output syndrome.

The ICU time and the in-hospital time did not differ among groups. The ventilation time in the obese group was significantly longer than that in the normal weight and overweight group ( $20.9 \mathrm{~h}$ vs $22.0 \mathrm{~h}$ vs $30.4 \mathrm{~h}$ for normal, overweight and obese, respectively; $P=0.039$ ). What's more, the proportion of ventilation time $>24 \mathrm{~h}$ in the overweight and obese patients was significantly

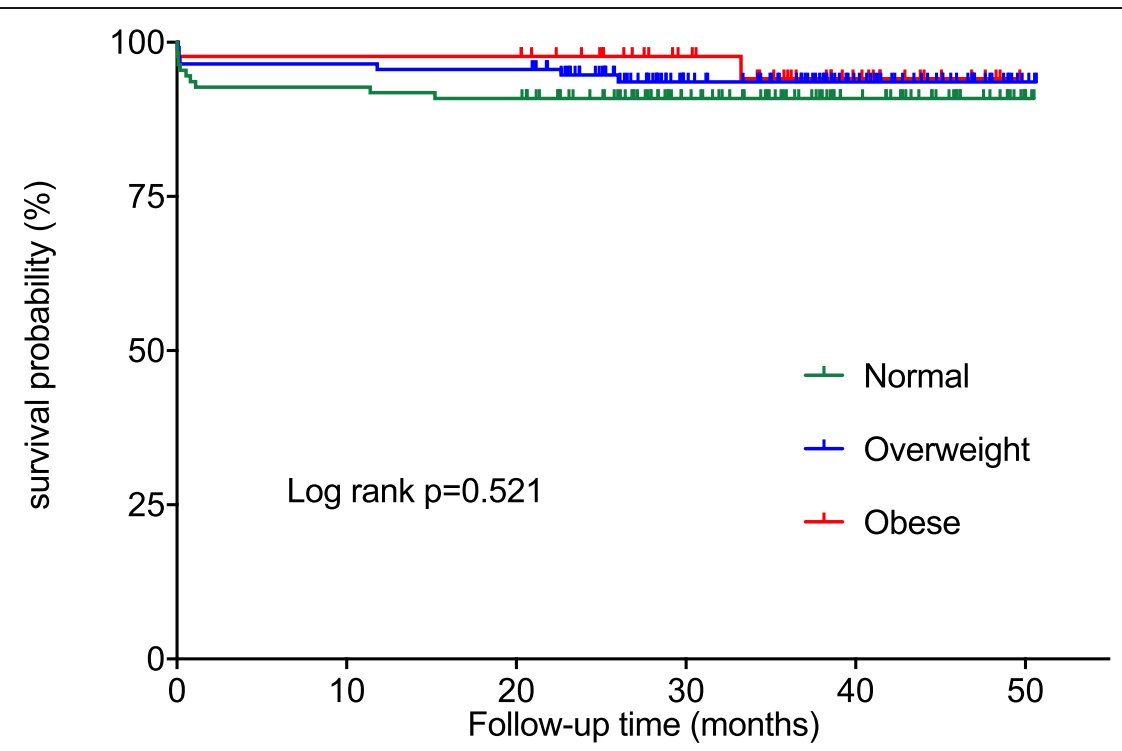

$\begin{array}{ll}\text { Number at risk } & \\ \text { Normal } & 110 \\ \text { Overweight } & 114 \\ \text { Obese } & 44\end{array}$

$\begin{array}{ccc}102 & 101 & 65 \\ 110 & 109 & 65 \\ 43 & 43 & 29\end{array}$

$\begin{array}{ll}34 & 4 \\ 36 & 3 \\ 14 & 0\end{array}$

Fig. 1 Kaplan-Meier analysis of the overall survival in normal weight (BMl 18.5 to $<25 \mathrm{~kg} / \mathrm{m}^{2}$ ), overweight (BMI 25 to $<30 \mathrm{~kg} / \mathrm{m}^{2}$ ) and obese (BMl $\geq 30 \mathrm{~kg} / \mathrm{m}^{2}$ ) patients with acute type A aortic dissection. BMl, body mass index 
higher than that in the normal weight patients, and the higher the obesity, the higher the proportion of ventilation duration $>24 \mathrm{~h}(34.5 \%$ vs $45.6 \%$ vs $59.1 \%$ for normal, overweight and obese, respectively; $P=0.017$ ).

Finally, no statistical difference was found among the BMI groups regarding the mid-term survival (Fig. 1; logrank test, $P=0.521$ ).

\section{Regression analysis}

The regression analysis for composite adverse events is showed in Table 4. According to the univariable and multivariable analysis, $\mathrm{BMI} \geq 25 \mathrm{~kg} / \mathrm{m}^{2}$ or $\mathrm{BMI} \geq 30 \mathrm{~kg}$ / $\mathrm{m}^{2}$ were not associated with composite adverse events. The independent predictors of composite adverse events were cardiac malpersuion (OR 4.019; 95\% CI 1.12814.322; $P=0.032$ ), cerebral malpersuion (OR 5.060; $95 \%$
CI 1.402-18.268; $P=0.013$ ), and limb malpersuion (OR 10.223; 95\% CI 2.266-46.124; $P=0.002$ ).

In the univariable regression analysis for ventilation time $>24 \mathrm{~h}$ (Table 5), several variables were associated with ventilation time $>24 \mathrm{~h}(P<0.1)$. BMI $\geq 30 \mathrm{~kg} / \mathrm{m}^{2}$ (OR 2.261; 95\% CI 1.056-4.838; $P=0.036$ ), moderate-tosevere aortic regurgitation (OR $0.492 ; 95 \%$ CI $0.249-$ $0.971 ; P=0.041)$ and transfusion amount of fresh frozen plasma (OR 1.001; 95\% 1.000-1.001; $P=0.019$ ) were identified as risk factors in the multivariable regression analysis.

\section{Discussion}

The main findings of the study were that obese patients with ATAAD undergoing TAR with FET achieve comparable early outcomes compared to normal weight and

Table 4 Univariable and multivariable logistic analysis for risk factors associated with composite adverse events

\begin{tabular}{|c|c|c|c|c|}
\hline \multirow[t]{2}{*}{ Risk factor } & \multicolumn{2}{|l|}{ Univariable analysis } & \multicolumn{2}{|l|}{ Multivariable analysis } \\
\hline & OR $(95 \% \mathrm{Cl})$ & $P$ value & OR $(95 \% \mathrm{Cl})$ & $P$ value \\
\hline Age (years) & $1.009(0.977-1.042)$ & 0.578 & & \\
\hline Male & $1.104(0.536-2.273)$ & 0.788 & & \\
\hline \multicolumn{5}{|l|}{ BMI $\left(\mathrm{kg} / \mathrm{m}^{2}\right)$} \\
\hline $\mathrm{BMI}<25$ & 1.000 & & & \\
\hline $\mathrm{BMI} \geq 25$ & $1.063(0.561-2.013)$ & 0.852 & & \\
\hline $\mathrm{BMI} \geq 30$ & $0.841(0.344-2.054)$ & 0.703 & & \\
\hline Hypertension & $0.700(0.335-1.462)$ & 0.343 & & \\
\hline CAD & $3.115(1.587-6.116)$ & 0.001 & $1.440(0.301-6.895)$ & 0.648 \\
\hline Diabetes & $1.272(0.250-6.478)$ & 0.772 & & \\
\hline Cerebrovascular events & $1.034(0.279-3.841)$ & 0.960 & & \\
\hline CKD & NS & NS & & \\
\hline $\mathrm{NYHA} \geq 3$ & $1.658(0.415-6.628)$ & 0.475 & & \\
\hline \multicolumn{5}{|l|}{ Organ malperfusion } \\
\hline Cardiac & $4.881(1.688-14.116)$ & 0.003 & $4.019(1.128-14.322)$ & 0.032 \\
\hline Cerebral & $4.120(1.275-13.315)$ & 0.018 & $5.060(1.402-18.268)$ & 0.013 \\
\hline Visceral & $1.267(0.129-12.416)$ & 0.839 & & \\
\hline Limb & $8.360(2.021-34.581)$ & 0.003 & $10.223(2.266-46.124)$ & 0.002 \\
\hline LVEF & $0.970(0.903-1.042)$ & 0.411 & & \\
\hline Median or massive AR & $0.551(0.261-1.162)$ & 0.117 & & \\
\hline Bentall & $1.142(0.592-2.201)$ & 0.692 & & \\
\hline CABG & $3.640(1.873-7.076)$ & $<0.001$ & $1.675(0.331-8.460)$ & 0.533 \\
\hline CPB time & $1.010(1.005-1.014)$ & $<0.001$ & $1.004(0.999-1.010)$ & 0.116 \\
\hline Cross-clamp time & $1.006(0.999-1.013)$ & 0.121 & & \\
\hline Circulatory arrest time & $1.045(0.963-1.134)$ & 0.294 & & \\
\hline \multicolumn{5}{|l|}{ Transfusion } \\
\hline Red blood cells & $1.274(1.122-1.447)$ & $<0.001$ & $1.144(0.970-1.348)$ & 0.109 \\
\hline Fresh frozen plasma & $1.001(1.000-1.002)$ & 0.002 & $1.000(1.000-1.001)$ & 0.308 \\
\hline Platelets & $1.196(0.947-1.511)$ & 0.134 & & \\
\hline
\end{tabular}


Table 5 Univariable and multivariable logistic analysis for risk factors associated with ventilation time $>24 \mathrm{~h}$

\begin{tabular}{|c|c|c|c|c|}
\hline \multirow[t]{2}{*}{ Risk factor } & \multicolumn{2}{|l|}{ Univariable analysis } & \multicolumn{2}{|c|}{ Multivariable analysis } \\
\hline & OR $(95 \% \mathrm{Cl})$ & $P$ value & OR $(95 \% \mathrm{Cl})$ & $P$ value \\
\hline Age (years) & $1.011(0.985-1.039)$ & 0.398 & & \\
\hline Male & $0.878(0.479-1.609)$ & 0.673 & & \\
\hline \multicolumn{5}{|l|}{$\mathrm{BMI}\left(\mathrm{kg} / \mathrm{m}^{2}\right)$} \\
\hline $\mathrm{BMI}<25$ & 1.000 & & 1.000 & \\
\hline $\mathrm{BMI} \geq 25$ & 1.589 (0.927-2.724) & 0.092 & $1.565(0.890-2.751)$ & 0.120 \\
\hline $\mathrm{BMI} \geq 30$ & $2.737(1.335-5.612)$ & 0.006 & $2.261(1.056-4.838)$ & 0.036 \\
\hline Hypertension & $1.474(0.758-2.865)$ & 0.253 & & \\
\hline$C A D$ & $2.442(1.293-4.610)$ & 0.006 & $1.508(0.353-6.440)$ & 0.579 \\
\hline Diabetes & $0.427(0.085-2.155)$ & 0.303 & & \\
\hline Cerebrovascular events & $1.802(0.608-5.347)$ & 0.288 & & \\
\hline CKD & $0.652(0.058-7.281)$ & 0.728 & & \\
\hline $\mathrm{NYHA} \geq 3$ & $0.869(0.239-3.154)$ & 0.831 & & \\
\hline \multicolumn{5}{|l|}{ Organ malperfusion } \\
\hline Cardiac & $0.867(0.300-2.508)$ & 0.792 & & \\
\hline Cerebral & $0.422(0.112-1.595)$ & 0.203 & & \\
\hline Visceral & $0.432(0.044-4.206)$ & 0.470 & & \\
\hline Limb & $2.709(0.663-11.070)$ & 0.165 & & \\
\hline LVEF & $1.021(0.959-1.087)$ & 0.510 & & \\
\hline Median or massive AR & $0.465(0.260-0.832)$ & 0.010 & $0.492(0.249-0.971)$ & 0.041 \\
\hline Bentall & $0.536(0.303-0.948)$ & 0.032 & $0.746(0.383-1.453)$ & 0.389 \\
\hline CABG & $2.176(1.170-4.047)$ & 0.014 & $1.549(0.374-6.421)$ & 0.546 \\
\hline CPB time & 1.002 (0.999-1.006) & 0.249 & & \\
\hline Cross-clamp time & $0.999(0.993-1.005)$ & 0.696 & & \\
\hline Circulatory arrest time & 1.051 (0.978-1.129) & 0.174 & & \\
\hline \multicolumn{5}{|l|}{ Transfusion } \\
\hline Red blood cells & $1.094(0.979-1.223)$ & 0.113 & & \\
\hline Fresh frozen plasma & $1.001(1.000-1.001)$ & 0.008 & $1.001(1.000-1.001)$ & 0.019 \\
\hline Platelets & $1.305(0.987-1.726)$ & 0.062 & $1.313(0.948-1.818)$ & 0.101 \\
\hline
\end{tabular}

$O R$ odds ratio, $\mathrm{Cl}$ confidence interval

overweight patients; obese patients require longer ventilation time than normal weight and overweight patients.

Obesity has long been recognised as a major risk factor for cardiovascular diseases including hypertension, coronary artery disease and heart failure $[8,9]$. However, the impact of obesity on cardiac surgery remains controversial. Some authors reported that obesity was related to worse outcomes after open heart surgery, with higher early mortality, worse late survival and increased rate of postoperative complications including renal failure, prolonged intensive care unit stay and sternal wound infection [1, 10-13]. While others have suggested the existence of a protective 'obesity paradox' in cardiac surgery, defined as a protective effect of obesity against early postoperative complications and late mortality [2, 14-17]. The influence of obesity on aortic dissection surgery appears to be similar in the current study. Maximilian Kreibich and his colleagues reported that obesity was not associated with a greater risk of death or other adverse outcomes in patients undergoing surgery for type A aortic dissection [3]. Yang Li and his colleagues also reported that BMI had no effect on in-hospital death and postoperative complications after open surgery for acute thoracic aortic dissection [4]. Consistent with these findings, the composite adverse events were also not associated with obesity in our study. In our previous article designed to explore the risk factors for major adverse outcomes in ATAAD, BMI was not identified as a risk factor. And the major adverse outcomes were more related to age, malperfusion syndrome and $\mathrm{CPB}$ time, which was in line with our current study [18]. 
Obesity represents a significant problem for the respiratory system, causing a number of physiological changes. Obesity is related to impaired pulmonary function, including increased residual lung volume, decreased lung compliance and increased chest wall impedance, ventilation-perfusion abnormalities, depressed ventilatory drive, and bronchospasm [19]. During postoperative ventilation, atelectasis is a significant problem for obese patients, which is associated to paralysis, sedation, and supine positioning [20, 21]. Moreover, obesity predisposes to obstructive sleep apnoea syndrome, which is a risk factor for difficult ventilation [22-24]. Therefore, obese patients are at increased risk of postoperative respiratory complications and require more specific respiratory management after surgery, which is reflected in our study as prolonged ventilation time in overweight and obese patients. This phenomenon has also been observed by Maximilian Kreibich and Yang $\mathrm{Li}$ in their studies [3, 4]. In addition, we found that moderate-tosevere aortic regurgitation and transfusion volume of fresh frozen plasma are the risk factors for prolonged ventilation time. This suggests that pulmonary congestion and pulmonary edema caused by aortic regurgitation and intraoperative fluid infusion are the reasons for decreased respiratory function.

Maximilian Kreibich and his colleagues reported similar long-term survival among all BMI groups in patients with type A aortic dissection, which was consistent with our findings [3]. Although obesity may increase the risk of hypertension, coronary heart disease, diabetes, etc., the long-term survival of patients with aortic dissection is mainly related to the progression of residual dissection, which is profoundly influenced by the location and size of remained tears [25]. This may explain the similar mid-term survival among the BMI groups.

\section{Limitations}

There are some limitations in our study. This study is limited by its non-randomized, single-centre, retrospective nature. Furthermore, the sample size was small, especially for obese group. There were no underweight and few morbidly obese (BMI $\geq 35 \mathrm{~kg} / \mathrm{m}^{2}$ ) patients in this study, which may be due to the demographic characteristics of China. Lastly, the long-term prognosis of patients with ATAAD in different groups should also be of concern. This study only reported the early and midterm outcomes. Future studies should pay more attention to late complications, quality of life, and cause of death.

\section{Conclusions}

BMI had no effect on the major adverse outcomes and mid-term survival after surgery for ATAAD. Satisfactory surgical outcomes can be obtained in patients with ATAAD at all weights.

\section{Abbreviations}

BMI: body mass index; ATAAD: acute Stanford type A aortic dissection; TAR

with FET: total arch replacement with frozen elephant trunk;

CPB: cardiopulmonary bypass; SCP: selective cerebral perfusion;

CABG: coronary artery bypass grafting

\section{Acknowledgements}

The authors are grateful to all the surgeons in the vascular surgery centre for providing the data.

\section{Authors' contributions}

(I) Conception and design: YL, XS; (II) Provision of study materials or patients: HL, HG, XS; (III) Collection and assembly of data: SL, BZ, YD; (IV) Data analysis and interpretation: $Y L_{;}(V)$ Manuscript writing: $Y L ;(V I)$ Final approval of manuscript: All authors.

\section{Funding}

This work was supported by the Beijing Municipal Science and Technology Commission (Z181100001718197).

Availability of data and materials

The datasets used and/or analyzed during the current study are available from the corresponding author on reasonable request.

\section{Declarations}

\section{Ethics approval and consent to participate}

This single-center retrospective cohort study was approved by the ethics committees of Fuwai Hospital and the written informed consent was waived due to the retrospective design.

\section{Consent for publication}

Consents for publication were obtained from all individuals involved in our study.

\section{Competing interests}

The authors declare that they have no competing interests.

Received: 15 September 2020 Accepted: 7 June 2021

Published online: 22 June 2021

\section{References}

1. Ghanta RK, LaPar DJ, Zhang Q, Devarkonda V, Isbell JM, Yarboro LT, et al. Obesity increases risk-adjusted morbidity, mortality, and cost following cardiac surgery. J Am Heart Assoc. 2017:6:e003831.

2. Mariscalco G, Wozniak MJ, Dawson AG, Serraino GF, Porter R, Nath M, et al. Body mass index and mortality among adults undergoing cardiac surgery: a Nationwide study with a systematic review and meta-analysis. Circulation. 2017;135(9):850-63. https://doi.org/10.1161/CIRCULATIONAHA.116.022840.

3. Kreibich M, Rylski B, Bavaria JE, Branchetti E, Dohle D, Moeller P, et al. Outcome after operation for aortic dissection type a in morbidly obese patients. Ann Thorac Surg. 2018;106(2):491-7. https://doi.org/10.1016/j.a thoracsur.2018.03.035.

4. $\quad$ Li Y, Jiang H, Xu H, Li N, Zhang Y, Wang G, Xu Z. Impact of a Higher Body Mass Index on Prolonged Intubation in Patients Undergoing Surgery for Acute Thoracic Aortic Dissection. Heart Lung Circ. 2020:514439506(20)30072-X.

5. Lio A, Bovio E, Nicolo F, Saitto G, Scafuri A, Bassano C, et al. Influence of body mass index on outcomes of patients undergoing surgery for acute aortic dissection: a propensity-matched analysis. Tex Heart Inst J. 2019;46(1): 7-13. https://doi.org/10.14503/THIJ-17-6365.

6. Liu ZG, Sun LZ, Chang Q, Zhu JM, Dong C, Yu CT, et al. Should the "elephant trunk" be skeletonized? Total arch replacement combined with stented elephant trunk implantation for Stanford type a aortic dissection. J Thorac Cardiovasc Surg. 2006;131(1):107-13. https://doi.org/10.1016/j.jtcvs.2 005.09.015.

7. Ma WG, Zhu JM, Zheng J, Liu YM, Ziganshin BA, Elefteriades JA, et al. Sun's procedure for complex aortic arch repair: total arch replacement using a 
tetrafurcate graft with stented elephant trunk implantation. Ann Cardiothorac Surg. 2013;2(5):642-8. https://doi.org/10.3978/j.issn.2225-319X.2 013.09.03.

8. Poirier P, Giles TD, Bray GA, Hong Y, Stern JS, Pi SFX, et al. Obesity and cardiovascular disease: pathophysiology, evaluation, and effect of weight loss: an update of the 1997 American Heart Association scientific statement on obesity and heart disease from the obesity Committee of the Council on nutrition, physical activity, and metabolism. Circulation. 2006;113(6):898-918. https://doi.org/10.1161/CIRCULATIONAHA.106.171016.

9. De Santo LS, Moscariello C, Zebele C. Implications of obesity in cardiac surgery: pattern of referral, physiopathology, complications, prognosis. J Thorac Dis. 2018;10(7):4532-9. https://doi.org/10.21037/jtd.2018.06.104.

10. Rahmanian PB, Adams DH, Castillo JG, Chikwe J, Bodian CA, Filsoufi F. Impact of body mass index on early outcome and late survival in patients undergoing coronary artery bypass grafting or valve surgery or both. Am J Cardiol. 2007;100(11):1702-8. https://doi.org/10.1016/j.amjcard.2007.07.017.

11. Benedetto U, Danese C, Codispoti M. Obesity paradox in coronary artery bypass grafting: myth or reality? J Thorac Cardiovasc Surg. 2014;147(5): 1517-23. https://doi.org/10.1016/j.jtcvs.2013.05.028.

12. van Straten AH, Bramer S, Soliman Hamad MA, van Zundert AA, Martens EJ, Scho"nberger JP et al. Effect of body mass index on early and late mortality after coronary artery bypass grafting. Ann Thorac Surg 2010;89:30-37, 1 DOl: https://doi.org/10.1016/j.athoracsur.2009.09.050.

13. Rapetto F, Bruno VD, King M, Benedetto U, Caputo M, Angelini GD, et al. Impact of body mass index on outcomes following mitral surgery: does an obesity paradox exist? Interact Cardiovasc Thorac Surg. 2018;26(4):590-5. https://doi.org/10.1093/icvts/ivx383.

14. Stamou SC, Nussbaum M, Stiegel RM, Reames MK, Skipper ER, Robicsek F, et al. Effect of body mass index on outcomes after cardiac surgery: is there an obesity paradox? Ann Thorac Surg. 2011;91(1):42-7. https://doi.org/10.1 016/j.athoracsur.2010.08.047.

15. Vaduganathan M, Lee R, Beckham AJ, Andrei AC, Lapin B, Stone NJ, et al. Relation of body mass index to late survival after valvular heart surgery. Am J Cardiol. 2012;1 10(11):1667-78. https://doi.org/10.1016/j.amjcard.2012.07.041.

16. Smith RL, Herbert MA, Dewey TM, Brinkman WT, Prince SL, Ryan WH, et al. Does body mass index affect outcomes for aortic valve replacement surgery for aortic stenosis? Ann Thorac Surg 2012:93:746-6; discussion 746-7.

17. Roberts WC, Roberts CC, Vowels TJ, Ko JM, Filardo G, Hamman BL, et al. Effect of body mass index on survival in patients having aortic valve replacement for aortic stenosis with or without concomitant coronary artery bypass grafting. Am J Cardiol. 2011;108(12):1767-71. https://doi.org/10.1016/.amjcard.2011.09.010.

18. Wei J, Chen Z, Zhang H, Sun X, Qian X, Yu C. In-hospital major adverse outcomes of acute type a aortic dissection. Eur I Cardiothorac Surg. 2019; 55(2):345-50. https://doi.org/10.1093/ejcts/ezy269.

19. Ray CS, Sue DY, Bray G, Hansen JE, Wasserman K. Effects of obesity on respiratory function. Am Rev Respir Dis. 1983;128(3):501-6. https://doi.org/1 0.1164/arrd.1983.128.3.501.

20. Eichenberger A, Proietti S, Wicky S, Frascarolo P, Suter M, Spahn DR, et al. Morbid obesity and postoperative pulmonary atelectasis: an underestimated problem. Anesth Analg. 2002;95(6):1788-92. https://doi.org/10.1097/0000053 9-200212000-00060.

21. Reinius $H$, Jonsson L, Gustafsson S, Sundbom M, Duvernoy O, Pelosi P, et al. Prevention of atelectasis in morbidly obese patients during general anesthesia and paralysis: a computerized tomography study. Anesthesiology. 2009;111(5): 979-87. https://doi.org/10.1097/ALN.0b013e3181b87edb.

22. De Jong A, Futier E, Millot A, Coisel Y, Jung B, Chanques G, et al. How to preoxygenate in operative room: healthy subjects and situations "at risk". Ann $\mathrm{Fr}$ Anesth Reanim. 2014;33(7-8):457-61. https://doi.org/10.1016/j.annfar.2014.08.001.

23. Romero-Corral A, Caples SM, Lopez-Jimenez F, Somers VK. Interactions between obesity and obstructive sleep apnea: implications for treatment. Chest. 2010;137(3):711-9. https://doi.org/10.1378/chest.09-0360.

24. Langeron O, Masso E, Huraux C, Guggiari M, Bianchi A, Coriat P, et al. Prediction of difficult mask ventilation. Anesthesiology. 2000;92(5):1229-36, https://doi.org/10.1097/00000542-200005000-00009.

25. Zhang S, Chen Y, Zhang Y, Shi D, Shen Y, Bao J, et al. Should the distal tears of aortic dissection be treated? The risk of distal tears after proximal repair of aortic dissection. Int J Cardiol. 2018;261:162-6. https://doi.org/10.1016/.j.jcard.2018.01.028.

\section{Publisher's Note}

Springer Nature remains neutral with regard to jurisdictional claims in published maps and institutional affiliations.

\section{Ready to submit your research? Choose BMC and benefit from:}

- fast, convenient online submission

- thorough peer review by experienced researchers in your field

- rapid publication on acceptance

- support for research data, including large and complex data types

- gold Open Access which fosters wider collaboration and increased citations

- maximum visibility for your research: over $100 \mathrm{M}$ website views per year

At $\mathrm{BMC}$, research is always in progress.

Learn more biomedcentral.com/submissions 